\title{
Tedanolide C: a potent new 18-membered ring cytotoxic macrolide isolated from the Papua New Guinea marine sponge Ircinia sp
}

\author{
Camille Chevallier $§$, Tim S. Bugni $§$, Xidong Feng ${ }^{\dagger}$, Mary Kay Harper $§$, Anita M. Orendt ${ }^{\ddagger}$, and \\ Chris M. Ireland $\S$, \\ § University of Utah, Department of Medicinal Chemistry, Salt Lake City, UT 84112, USA \\ $\dagger$ Wyeth Research, Pearl River, NY 10965, USA \\ \$ University of Utah, Center for High Performance Computing, Salt Lake City, UT 84112, USA
}

\begin{abstract}
Cytotoxicity-guided fractionation of the crude methanol extract of a marine sponge, Ircinia sp., yielded tedanolide $\mathrm{C}(\mathbf{1})$, a new 18-membered macrolide. The structure was solved by interpreting NMR and MS data, and the relative stereochemistry was determined from a combination of homo and heteronuclear coupling constants in conjunction with molecular modeling. Compound 1 exhibited potent cytotoxicity against HCT-116 cells in vitro. Cell cycle analysis showed that treatment of cells with compound $\mathbf{1}$ arrested cells in S-phase.
\end{abstract}

\begin{abstract}
The promising bioactivity and the structural diversity within the marine environment continue to yield new secondary metabolites. ${ }^{1}$ The encouraging current number of marine natural products and related compounds in clinical and advanced preclinical trials is evidence that marine secondary metabolites are important sources of new drug. ${ }^{2}$ As part of our natural products screening program for new anticancer lead compounds, ${ }^{3}$ the extract of the marine sponge, Ircinia sp. collected in Milne Bay, Papua New Guinea was shown to be very active in cytotoxicity assays against an HCT-116 cell line. Cytotoxicity-guided fractionation of the extract yielded (1), a new highly potent 18-membered macrolide. Over the past few years, several classes of macrolides have been isolated from marine sponges. These include two closely related 18-membered macrolides, tedanolide (2) ${ }^{4}$ and 13-deoxytedanolide $(\mathbf{3})^{5}$ from Tedania ignis and Mycale adhaerens, respectively, laulimalide, ${ }^{6}$ a 20 -membered ring from Cacospongia mycofijiensis, Hyatella sp., Fasciospongia sp., Dactylospongia sp., and also from a chromodorid nudibranch, and peloruside A, ${ }^{7}$ a 16-membered ring macrolide from Mycale hentscheli. Tedanolide $\mathrm{C}(\mathbf{1})$ has the same macrolide ring size as tedanolide and 13deoxytedanolide but a different oxygenation and methylation pattern. Herein, we report the isolation, the structure elucidation, the relative stereochemistry, cytotoxic evaluation of tedanolide C (1) and its activity on the cell cycle progression of HCT-116 cells.
\end{abstract}

\footnotetext{
*To whom correspondence should be addressed. Tel: 801-581-8305. Fax: 801-585-6208 cireland@ pharm.utah.edu.

$\S_{\text {University of Utah, Medicinal Chemistry Department }}$

${ }^{\dagger}$ Wyeth Research

Wuniversity of Utah, Center for High Performance Computing

Supporting Information Available: Copies of ${ }^{1} \mathrm{H},{ }^{13} \mathrm{C}$, DQF-COSY, GHSQC, GHMBC, GHETLOC and G-BIRDR-HSQMBC NMR data, general experimental procedures, fragmentation pathway for the $[\mathrm{M}+\mathrm{Na}]^{+}$ion observed in the ESI FTMS SORICID mass spectrum for 1 , biological assay descriptions and three-dimensional structure of 1 . This material is available free of charge via the internet at http://pubs.acs.org.
} 
The specimen of Ircinia collected from Papua New Guinea was extracted with $\mathrm{MeOH}$. The crude extract was subjected to a solvent partition scheme to yield hexane, $\mathrm{CHCl}_{3}$, and aqueous $\mathrm{MeOH}$ extracts. The $\mathrm{CHCl}_{3}$ extract was subjected to reversed-phase flash column chromatography using a $\mathrm{MeOH} / \mathrm{H}_{2} \mathrm{O}$ gradient. The fraction eluting with (50:50) $\mathrm{MeOH} / \mathrm{H}_{2} \mathrm{O}$ was concentrated to provide $145.4 \mathrm{mg}$ of material that was further separated by HPLC using a reversed-phase semi-preparative column to provide $15.7 \mathrm{mg}$ of tedanolide $\mathrm{C}$ (1) $(0.003 \%$ wet weight).

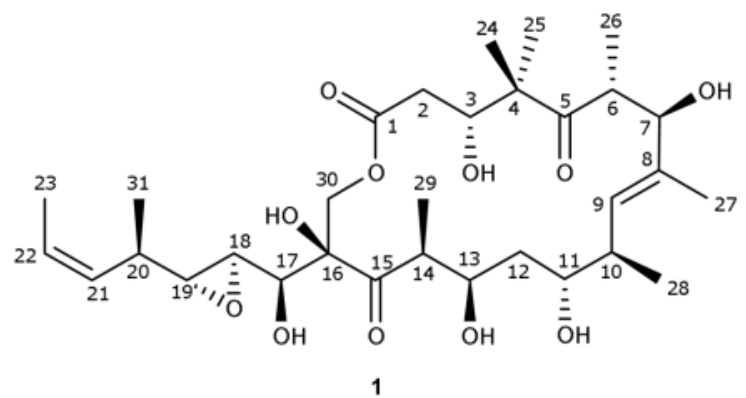

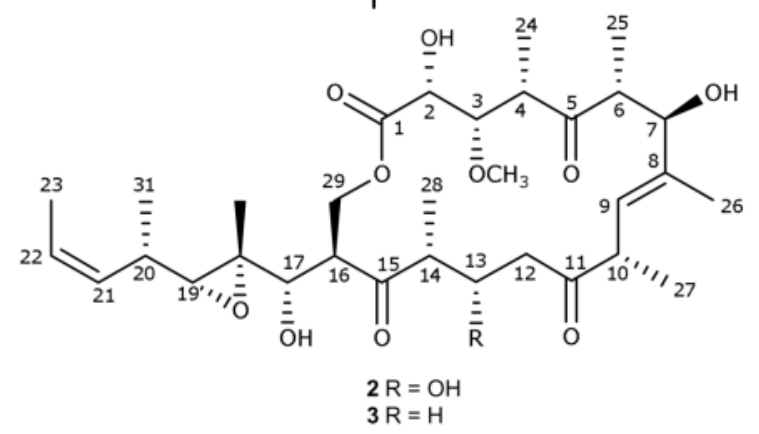

Compound 1 was obtained as a white amorphous solid. The HRESEVIS gave an $[\mathrm{M}+\mathrm{Na}]^{+}$ion at $m / z 621.3242$ (calcd 621.3250) corresponding to the formula $\mathrm{C}_{31} \mathrm{H}_{50} \mathrm{O}_{11} \mathrm{Na}^{+}$, which was consistent with both the ${ }^{1} \mathrm{H}$ and ${ }^{13} \mathrm{C}$ NMR spectra. The IR spectrum contained absorption bands for hydroxyl, ester, and ketone groups $\left(3418,1736,1697 \mathrm{~cm}^{-1}\right) .{ }^{13} \mathrm{C}$ and DEPT experiments confirmed the presence of 31 carbons, which were distributed as six quaternary, fourteen methine, three methylene and eight methyl carbon atoms. Additionally, these spectra revealed the presence of two saturated ketone carbonyls, one ester carbonyl, one quaternary olefin carbon, three protonated olefinic carbons, seven oxymethine carbons and one quaternary oxygenated carbon. This carbon inventory explained five of the seven degrees of unsaturation, indicating 1 is bicyclic. The ${ }^{1} \mathrm{H}$ NMR spectrum revealed three downfield olefinic protons, seven downfield oxymethine protons, three methylene groups, four up field methine protons attached to carbons bearing methyls, four corresponding aliphatic secondary methyl groups (doublets), two upfield tertiary methyl groups (singlets) and two vinyl methyls (one singlet, one doublet) (see Table 1). Cross-peaks in the COSY spectrum indicated five continuous spin systems. Thereafter, these data along with HSQC, HSQC-TOCSY and HMBC data allowed assignments of the five partial structures shown in Figure 1.

For partial structure $\mathrm{A},{ }^{1} \mathrm{H}$ and ${ }^{13} \mathrm{C}$ chemical shifts indicated the presence of one $Z$ double bond $\left(J_{21,22}=10.8 \mathrm{~Hz}\right)$ between C-21 [ $\left.\delta_{\mathrm{H}} 5.27 ; \delta_{\mathrm{C}} 131.6\right]$ and C-22 [ $\left.\delta_{\mathrm{H}} 5.54 ; \delta_{\mathrm{C}} 127.1\right] . \mathrm{C}-17$ was oxygenated as judged by chemical shifts $\left[\delta_{\mathrm{H}} 3.51 ; \delta_{\mathrm{C}} 75.1\right]$. The methine proton $\mathrm{H}-20$ showed an $\mathrm{HMBC}$ correlation with the methyl carbon $\mathrm{C}-31[\delta 18.0]$. Based on ${ }^{1} \mathrm{H}$ and ${ }^{13} \mathrm{C}$ chemical shift data, C-19 $\left[\delta_{\mathrm{H}} 2.74 ; \delta_{\mathrm{C}} 62.3\right]$ and $\mathrm{C}-18\left[\delta_{\mathrm{H}} 2.99 ; \delta_{\mathrm{C}} 59.1\right]$ was part of a trans $\left(J_{18,19}=\right.$ $2.0 \mathrm{~Hz}$ ) epoxide and was confirmed by comparison with data from tedanolide ${ }^{4}$ and $13-$ deoxytedanolide. ${ }^{5}$ An HMBC correlation between the methine proton $\mathrm{H}-17$ [ $\left.\delta 3.51\right]$ and the 
oxygenated carbon C-16 [ $\delta 84.5]$ established the last connection for the remaining portion of the partial structure A. Partial structures D and E were established by interpretation of COSY and $\mathrm{HMBC}$ spectra. The contiguous nature of C-9 through C-14 in partial structure $\mathrm{D}$ was easily assigned from the COSY spectrum. C-11 and C-13 were oxygenated, based on their ${ }^{13} \mathrm{C}$ chemical shifts, $\delta 73.8$ and 70.2 , respectively. The ${ }^{1} \mathrm{H}$ and ${ }^{13} \mathrm{C}$ chemical shifts of $\mathrm{C}-9$ $\left[\delta_{\mathrm{H}} 5.18 ; \delta_{\mathrm{C}} 134.1\right]$ indicated it was part of a trisubstituted double bond. NOE correlations between the methyl group $\mathrm{H}_{3}-27$ and the proton $\mathrm{H}-10$ showed that the C-8-C-9 double bond was in the $E$ configuration Partial structure $E$ shared a characteristic COSY pattern for the sequence $\mathrm{CH}\left(\mathrm{CH}_{3}\right) \mathrm{CH}(\mathrm{OH})$. This piece was connected to $\mathrm{C}-8$ by an $\mathrm{HMBC}$ correlation with $\mathrm{H}-6$ and to $\mathrm{C}-5$ by an HMBC correlation from $\mathrm{H}-6$.

Partial structure $\mathrm{C}$ was deduced by a combination of COSY and HMBC data. The COSY spectrum revealed the C-2-C-3 unit. A quaternary carbon at 853.2 showing $\mathrm{HMBC}$ correlations with $\mathrm{H}-3, \mathrm{H}_{3}-24$ and $\mathrm{H}_{3}-25$ could be assigned as $\mathrm{C}-4$.

The ${ }^{1} \mathrm{H}$ shifts for $\mathrm{H}_{2}-30(\delta 4.02,4.18)$ indicated that these protons were an oxymethylene that displayed clear HMBC correlations to the ester carbonyl C-1 ( $\delta$ 172.6) and to the quaternary oxygenated carbon $\mathrm{C}-16(\delta 84.5)$. Long-range proton coupling correlations from the oxymethine proton $\mathrm{H}-17$ to carbons $\mathrm{C}-15$, and $\mathrm{C}-16$ and from methylenic proton $\mathrm{H}_{2}-30$ to ketone $\mathrm{C}-15$ revealed the attachment points between $\mathrm{C}-15-\mathrm{C}-16-\mathrm{C}-30$. The attachment point provided supportive evidence for the connection of partial structures A, B and D. Cross-peaks in the HMBC spectrum from $\mathrm{H}_{3}-24$ to C-5, $\mathrm{H}-6$ to $\mathrm{C}-5$ and from $\mathrm{H}_{3}-26$ to C-5 allowed connection of partial structures $\mathrm{C}$ and E. Proton $\mathrm{H}_{2}-2$ showed an HMBC correlation to C-1, linking partial structures B and C.

Initially, we planned to establish the relative stereochemistry using the $J$-based configuration analysis ${ }^{8}$ and DPFGSE $1 \mathrm{D} \mathrm{NOE}^{9}$ experiments in conjunction with molecular modeling. Several limitations regarding compound $\mathbf{1}$ made it clear that we had to take an iterative approach that combined extensive molecular modeling studies with an extension ${ }^{10}$ of $J$-based method followed by repetitive adjustments to the structure and finally DFT calculations on the intact molecule. Measurement of homonuclear coupling data was achieved utilizing ${ }^{1} \mathrm{H}$, and DQFCOSY experiments. Heteronuclear couplings were measured using a GHETLOC ${ }^{11}$ and a GBIRD $_{R}$-HSQMBC. ${ }^{12}$ A lowest energy conformer was first identified by molecular dynamics using AMBER. ${ }^{13}$ Subsequently, GAUSSIAN03 ${ }^{14}$ was used for geometry optimization (d95** basis set, B3LYP density functional) of the system and computation of $J$ values on the intact molecule (EPRn basis set, B3LYP density functional). ${ }^{15}$ The complete approach we used to help elucidate the relative stereochemistry, as well as a detailed account of the Gaussian calculations and evaluation of basis sets using model compounds will be presented elsewhere.

The epoxide was the starting point for the assignment of the relative stereochemistry.

The ${ }^{1} J_{\mathrm{HH}}$ for $\mathrm{H}-18$ and $\mathrm{H}-19,2.0 \mathrm{~Hz}$, is typical of a trans substituted epoxide. ${ }^{16}$ The coupling constant between H-19 and H-20 was large in $\mathbf{1}(6.9 \mathrm{~Hz})$ and in tedanolide $(9.4 \mathrm{~Hz})^{4}$, but the stereochemistry of C-20 could still be different between the two compounds. This large homonuclear coupling suggested an anti relationship in $\mathbf{1}$ between these two protons. Measurement of ${ }^{2} J_{\mathrm{CH}}$ coupling constant of $-7.0 \mathrm{~Hz}$ between H-20 and C-19 indicated that $\mathrm{H}-20$ was gauche to the electronegative oxygen substituent at C-19. Two ${ }^{3} J_{\mathrm{CH}}$ of 1.3 and 2.6 $\mathrm{Hz}$ between $\mathrm{H}-19$ and $\mathrm{C}-21$, and $\mathrm{H}-19$ and C-31 respectively indicated that this proton was gauche to these two groups. A NOESY correlation was observed between $\mathrm{H}-20$ and H-23. Only one rotamer (see Figure 3 ) fits all these data and thus represents the relative configuration of these two centers. $J$ coupling values have been computed for each rotamer about the C-19C-20 bond (see Figure 2). The calculated values $(-7.7$ and $6.1 \mathrm{~Hz}$ ) for the erythro $(-)$ gauche rotamer $\left({ }^{13} \mathrm{C}\right.$-attached oxygen relative to the proton) showed the best correlation to the experimental data ( -7.0 and $6.3 \mathrm{~Hz}$ respectively) for the C-19-C-20 bond of $\mathbf{1}$, providing 
additional support for the assigned stereochemistry. Measured and calculated ${ }^{2} J_{\mathrm{C} 20-\mathrm{H} 19}$ are large, positive values with no angular dependence. Based on the energies (Figure 2), the Boltzmann distribution indicates that the threo system should be mostly in the (-) gauche conformation. This result clearly does not agree with our experimental data, especially the ${ }^{3} J_{\mathrm{H} 19-\mathrm{H} 20}$ and ${ }^{2} J_{\mathrm{C} 19-\mathrm{H} 20}$.

For the C-17-C-18 bond, a large vicinal coupling constant between H-17 and H-18 (7.4 Hz) suggested that $\mathrm{H}-17$ and $\mathrm{H}-18$ were anti. A large two-bond $\mathrm{C}-\mathrm{H}$ coupling constant measured for $\mathrm{C}-18 / \mathrm{H}-17(4.0 \mathrm{~Hz})$ suggested that $\mathrm{H}-17$ was gauche to $18-\mathrm{OR}$. At this point the number of possible rotamers that would allow a large coupling constant between $\mathrm{H}-17$ and H-18 is still two. From the calculated and measured vicinal ${ }^{1} \mathrm{H}$ coupling, there is no evidence of conformational averaging. A NOESY correlation was observed between H-17 and H-19. Thus the relation between 17-OH and 18-OR was assigned as anti based on these data.

The relative stereochemistry at position C-16 was established through the $J$-based analysis for C-16-C-17 and C-16-C-30 bonds. Measurement of a small ${ }^{2} J_{\mathrm{C} 16-\mathrm{H} 17}(2.0 \mathrm{~Hz})$ and small ${ }^{3} J_{\mathrm{C} 15-\mathrm{H} 17}(1.7 \mathrm{~Hz})$ coupling constants, indicated that $\mathrm{H}-17$ was anti to $16-\mathrm{OH}$ and gauche to C-15. At this point, two rotamers satisfied these data. Molecular modeling was used to predict NOE patterns for each rotamer. One rotamer could be eliminated due to an observed NOE correlation between $\mathrm{H}-30 \mathrm{a} / \mathrm{H}-18$ which suggested a gauche orientation between these two protons. For the C-16-C-30 bond, a large ${ }^{2} J_{\mathrm{C} 16-\mathrm{H} 30 \mathrm{a}}(5.0 \mathrm{~Hz})$, a large ${ }^{3} J_{\mathrm{C} 15-\mathrm{H} 30 \mathrm{a}}(5.5 \mathrm{~Hz})$ and a small ${ }^{3} J_{\mathrm{C} 15-\mathrm{H} 30 \mathrm{~b}}(1.5 \mathrm{~Hz})$ heteronuclear couplings were measured, indicating that $\mathrm{H}-30 \mathrm{a}$ was gauche to $16-\mathrm{OH}$, anti to $\mathrm{C}-15$ and that $\mathrm{H}-30 \mathrm{~b}$ was gauche to $\mathrm{C}-15$. NOE correlations between $\mathrm{H}-30 \mathrm{a} / \mathrm{H}-17$ and $\mathrm{H}-30 \mathrm{~b} / \mathrm{H}-17$ finally established the relative stereochemistry depicted in Figure 3.

The relative orientation of H-9 and H-10 was demonstrated by a large homonuclear ${ }^{3} J_{\mathrm{H} 9-\mathrm{H} 10}$ $(9.2 \mathrm{~Hz})$ coupling constant, which suggested that these two protons should have an anti relationship and created confusion. However, a careful analysis of the best minimized molecular model revealed that the two protons were eclipsed. The two protons, $\mathrm{H}-9$ and $\mathrm{H}-10$, considered as eclipsed, indicated the relative stereochemistry depicted in Figure 3.

The rest of the stereocenters were also established using $J$-based analysis (see Figure 3 ). The relations between fragments were established through NOESY correlations analysis. NOESY correlations were observed for H-3/H-24, H-24/H-6, suggesting that H-3, H-6 and H-24 had gauche orientations. Similarly, fragments D and E (Figure 1) were related through an NOE correlation for H-6/H-27, H-27/H-28 and H-14/H-3. As explained above, for the determination of the relative stereochemistry at position C-16, fragments A, B and D (Figure 1) were related through the $J$-based analysis for C-16-C-17 and C-16-C-30 bonds and through observed NOESY correlations for $\mathrm{H}-30 \mathrm{a} / \mathrm{H}-17$ and $\mathrm{H}-30 \mathrm{~b} / \mathrm{H}-17$ in conjunction with molecular modeling.

Compound 1 was tested against a colorectal cancer cell line (HCT-116, wild type) and displayed an $\mathrm{IC}_{50}$ of $0.057 \mu \mathrm{g} / \mathrm{mL}\left(9.53 \times 10^{-8} \mathrm{M}\right)$. Cell cycle analysis showed that treatment of HCT- 116 cells with $0.2 \mu \mathrm{g} / \mathrm{mL}$ tedanolide $\mathrm{C}$ (1) resulted in a strong accumulation of cells in the S-phase after 24-h exposure and was sustained through 48-h exposure (see Figure 4). These potent results indicated that like 13-deoxytedanolide, ${ }^{17}$ tedanolide $\mathrm{C}(\mathbf{1})$ could be an inhibitor of protein synthesis.

In conclusion, tedanolide $\mathrm{C}(\mathbf{1})$ is a new 18-membered macrolide isolated from the Papua New Guinea sponge Ircinia sp. This compound bears a different pattern of oxygenation and methylation when compared to tedanolide ${ }^{4}$ and 13 -deoxytedanolide. ${ }^{5}$ The planar structure was established mainly by NMR methods. An extension of the $J$-based configuration analysis was applied successfully in conjunction with molecular modeling and DFT calculations to elucidate the relative stereochemistry of compound $\mathbf{1}$. We have identified a method to extend the $J$-based 
method for conformers that present anti relationships between adjacent protons. Since the coupling constant pattern is identical for erythro and threo systems, normally the $J$-based method does not allow the stereochemical assignment. However, using the energies obtained from Gaussian for each possible rotamer from two diastereoisomers, one can use Boltzmann's equation to estimate the populations. Using this approach, we found that the threo diastereoisomer should be mostly in the (-) gauche conformation. This conformer clearly does not agree with the measured coupling values. Tedanolide $\mathrm{C}(\mathbf{1})$ exhibited potent cytotoxicity against HCT-116 cells in vitro with $\mathrm{IC}_{50}$ value of $9.53 \times 10^{-8} \mathrm{M}$ and caused a strong S-phase arrest. A recent study of SARs of 13-deoxytedanolide ${ }^{5}$ reported that the southern hemisphere comprised the pharmacophore, while the epoxide-bearing side chain was essential for the activity. ${ }^{18}$ It has also been shown that 13 -deoxytedanolide ${ }^{5}$ is also a potent protein synthesis inhibitor and the first macrolide to inhibit the eukaryotic ribosome. ${ }^{17}$ The study of the mechanism of action of compound $\mathbf{1}$, as S-phase arrest agent, is currently under investigation.

\section{Experimental Section}

\section{Animal Material}

The specimen of Ircinia sp. was collected in Milne Bay (S $10^{\circ} 14.278^{\prime}$ E $\left.150^{\circ} 54.782^{\prime}\right)$, Papua New Guinea, in 2001. A voucher specimen (PNG01-6-67) is held at the University of Utah.

\section{Extraction and Isolation}

Frozen sponge material $(480 \mathrm{~g})$ was extracted with $\mathrm{MeOH}(1 \mathrm{~L})$ three times. The $\mathrm{MeOH}$ extracts were combined, filtered, and evaporated to dryness in vacuo to give a dark brown residue $(16.5 \mathrm{~g})$. This residue was dissolved in $10 \%$ water in $\mathrm{MeOH}(500 \mathrm{~mL})$ and partitioned against hexane $(3 \times 500 \mathrm{~mL})$. The water content of the $\mathrm{MeOH}$ phase was adjusted to $30 \%$ by adding $143 \mathrm{~mL}$ of water before partitioning against $\mathrm{CHCl}_{3}(3 \times 500 \mathrm{~mL})$. This solvent partition scheme yield hexane $(1.1 \mathrm{~g}), \mathrm{CHCl}_{3}(1.8 \mathrm{~g})$ and $30 \%$ aq $\mathrm{MeOH}(13.3 \mathrm{~g})$ extracts. The $\mathrm{CHCl}_{3}$ extract was fractionated by CIS flash column chromatography using $\mathrm{MeOH}$ gradients in $\mathrm{H}_{2} \mathrm{O}$. The last fraction eluted with (50:50) $\mathrm{MeOH} / \mathrm{H}_{2} \mathrm{O}(145.4 \mathrm{mg}$ ) was further purified by phenyl hexyl $\mathrm{HPLC}$ using a $\mathrm{CH}_{3} \mathrm{CN} / \mathrm{H}_{2} \mathrm{O}$ gradient (30:70 to $85: 15$ over $30 \mathrm{~min}$ ) to afford tedanolide $\mathrm{C}(1,15.7 \mathrm{mg})$.

Tedanolide C (1): white amorphous solid ; $[\alpha]^{24} \mathrm{D}+21.4^{\circ}$ (c $\left.0.215 ; \mathrm{MeOH}\right) ; \mathrm{UV}(\mathrm{MeOH})$ $\lambda_{\max }(\varepsilon) 208$ (8031) 264 (1096) nm ; IR (film) $v_{\max } 3418,2972,2933,1736,1697,1457,1372$, $1294,1253,1169,1076,984,903,822,756 \mathrm{~cm}^{-1} ;{ }^{1} \mathrm{H}$ and ${ }^{13} \mathrm{C}$ NMR data in Table 1; (+)LRESIMS $m / z$ [M+Na] ${ }^{+} 621.3$; HRESIMS $m / z 621.32423$ (calcd for $\mathrm{C}_{31} \mathrm{H}_{50} \mathrm{O}_{11} \mathrm{Na}^{+}$, $621.32508, \Delta-0.85 \mathrm{mmu})$.

\section{Acknowledgements}

This work was supported by NIH Grant CA36622. Funding for the Varian Inova $500 \mathrm{MHz}$ NMR spectrometer was provided through NCI Grant No. 5 P30 CA 42014 and NIH Grant No. 1 S10RR06262. The authors wish to acknowledge Papua New Guinea government for permits to collect the sponge and also Anna Senina and the HSC core facilities for performing the cell proliferation assay and the flow cytometry experiments, respectively. An allocation of computer time from the Center for High Performance Computing at the University of Utah is gratefully acknowledged. The computational resources for this project have been provided by the National Institutes of Health (Grant \# NCRR 1 S10 RR17214-01) on the Arches Metacluster, administered by the University of Utah Center for High Performance Computing. We thank Mr. Jay Olsen, University of Utah for his assistance in acquiring NMR data.

\section{References and Footnotes}

1. Blunt JW, Copp BR, Munro MHG, Northcote PT, Prinsep MR. Nat Prod Rep 2004;21:1-49. [PubMed: 15039834]

2. Newman DJ, Cragg GMJ. Nat Prod 2004;67:1216-1238. 
3. Ireland CM, Aalbersberg W, Andersen RJ, Ayral-Kaloustian S, Berlinck R, Bernan V, Carter G, Churchill ACL, Clardy J, Concepcion GP, Dilip De Silva E, Discafani C, Fojo T, Frost P, Gibson D, Greenberger LM, Greenstein M, Harper MK, Mallon R, Loganzo R, Nunes M, Poruchynsky MS, Zask A. Pharm Biol 2003;41(supplement 1):15-38.

4. Schmitz FJ, Gunasekera SP, Yalamanchili G, Bilayet Hossain M, Van Der Helm DJ. Am Chem Soc 1984;106:7251-7252.

5. Fusetani N, Sugawara T, Matsunaga S, Hirota HJ. Org Chem 1991;56:4971-4974.

6. (a) Corley DG, Herb R, Moore RE, Scheuer PJJ. Org Chem 1988;55:3644-3646. (b) Jefford CW, Bernadinelli G, Tanaka J, Higa T. Tetrahedron Lett 1996;37:159-162. (c) Mooberry SL, Tien G, Hernandez AH, Plubrukarn A, Davidson BS. Cancer Res 1999;59:653-660. [PubMed: 9973214]

7. (a) West LM, Northcote PT, Battershill CNJ. Org Chem 2000;65:445-449. (b) Hood KA, West LM, Rouwe B, Northcote PT, Berridge MV, Wakefield St J, Miller JH. Cancer Res 2002;62:3356-3360. [PubMed: 12067973]

8. Matsumori N, Kaneno D, Murata M, Nakamura H, Tachibana KJ. Org Chem 1999;64:866-876.

9. (a) Stott K, Stonehouse J, Keeler J, Hwang TL, Shaka AJJ. Am Chem Soc 1995;117:4199-4200. (b) Stott K, Keeler JN, Van Q, Shaka AJJ. Magn Reson 1997;125:302-324.

10. Williamson RT, Marquez BL, Barrios Sosa AC, Koehn FE. Magn Reson Chem 2003;41:379-385.

11. Uhrin D, Batta G, Hruby VJ, Barlow PN, Kover KEJ. Magn Reson 1998;130:155-161.

12. (a) Williamson RT, Marquez BL, Gerwick WH, Kover KE. Magn Reson Chem 2000;38:265-273. (b) Marquez BL, Gerwick WH, Williamson RT. Magn Reson Chem 2001;39:499-530. (c) Williamson RT, Boulanger A, Vulpanovici A, Roberts MA, Gerwick WHJ. Org Chem 2001;39:499_ 530.

13. Case DA, Darden TA, Cheathamm TE, Simmerling CL, Wang J, Duke RE, Luo R, Merz KM, Wang B, Pearlman DA, Crowley M, Brozell S, Tsui V, Gohlke H, Mongan J, Hornak V, Cui G, Beroza P, Schafmeister C, Caldwell JW, Ross WS, Kollman PA. AMBER.

14. Frisch, MJ.; Trucks, GW.; Schlegel, HB.; Scuseria, GE.; Robb, MA.; Cheeseman, JR.; Montgomery, JA., Jr; Vreven, T.; Kudin, KN.; Burant, JC.; Millam, JM.; lyengar, SS.; Tomasi, J.; Barone, V.; Mennucci, B.; Cossi, M.; Scalmani, G.; Rega, N.; Petersson, GA.; Nakatsuji, H.; Hada, M.; Ehara, M.; Toyota, K.; Fukuda, R.; Hasegawa, J.; Ishida, M.; Nakajima, T.; Honda, Y.; Kitao, O.; Nakai, H.; Klene, M.; Li, X.; Knox, JE.; Hratchian, HP.; Cross, JB.; Bakken, V.; Adamo, C.; Jaramillo, J.; Gomperts, R.; Stratmann, RE.; Yazyev, O.; Austin, AJ.; Cammi, R.; Pomelli, C.; Ochterski, JW.; Ayala, PY.; Morokuma, K.; Voth, GA.; Salvador, P.; Dannenberg, JJ.; Zakrzewski, VG.; Dapprich, S.; Daniels, AD.; Strain, MC.; Farkas, O.; Malick, DK.; Rabuck, AD.; Raghavachari, K.; Foresman, JB.; Ortiz, JV.; Cui, Q.; Baboul, AG.; Clifford, S.; Cioslowski, J.; Stefanov, BB.; Liu, G.; Liashenko, A.; Piskorz, P.; Komaromi, L.; Martin, RL.; Fox, DJ.; Keith, T.; Al-Laham, MA.; Peng, CY.; Nanayakkara, A.; Challacombe, M.; Gill, PMW.; Johnson, B.; Chen, W.; Wong, MW.; Gonzalez, C.; Pople, JA. Gaussian 03, Revision C.02. Gaussian, Inc; Wallingford CT: 2004.

15. Dunning, TH.; Hay, PJ, Jr. Methods of Electronic Structure Theory. Schaefer, HF., III, editor. 3. Plenum Press; New York: 1976. (b) Becke ADJ. Chem Phys 1993;98:5648-5652. (c) Lee C, Yang W, Parr RG. Phys Rev B 1988;37:785-789. (d) Stevens PJ, Devlin FJ, Chabalovwski CR, Frisch MJJ. Phys Chem 1994;98:11623-11627.Barone, V. Recent Advances in Density Functional Methods. Chong, DP., editor. World Scientific Publ. Co; Singapore: 1996. Part I

16. (a) Tsuda M, Sasaki T, Kobayashi JJ. Org Chem 1994;59:3734-3737. (b) Shigemori H, Tanaka Y, Yazawa K, Mikami Y, Kobayashi J. Tetrahedron 1996;52:9031-9034.

17. Nishimura S, Matsunaga S, Yoshida M, Hirota H, Yokoyama S, Fusetani N. Bioorg Med Chem 2005;13:449-454. [PubMed: 15598566]

18. Nishimura S, Matsunaga S, Yoshida S, Nakao Y, Hirota H, Fusetani N. Bioorg Med Chem 2005;13:455-462. [PubMed: 15598567] 

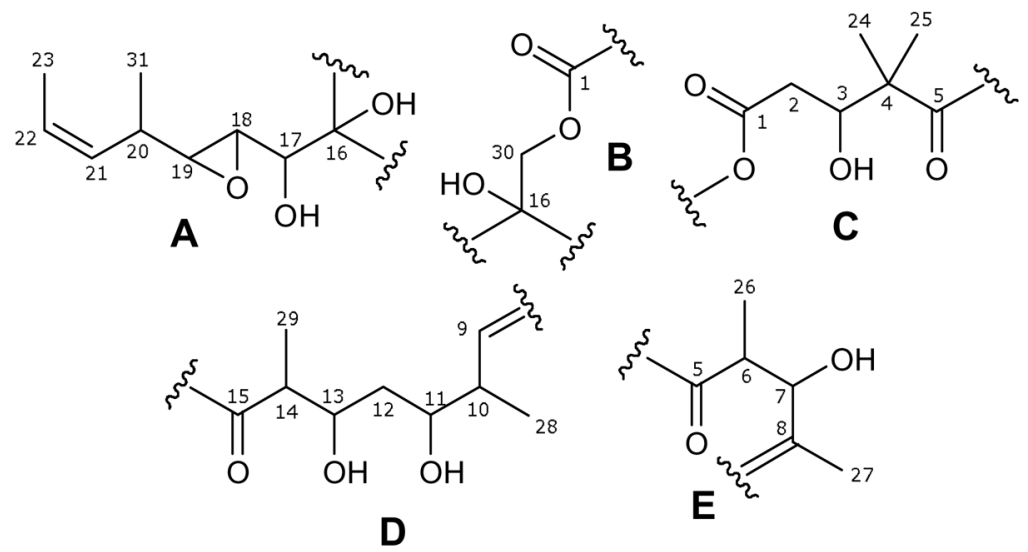

Figure 1.

Partial structures A-E determined for tedanolide C (1). 


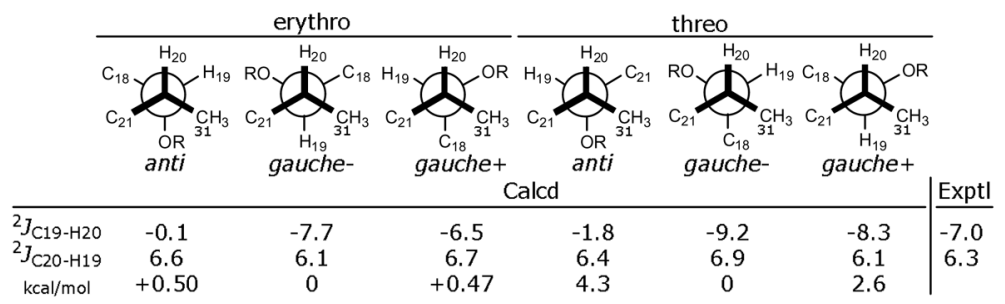

Figure 2.

Energies, Newman projections and comparison of experimental and calculated $J$ values for C-19-C-20 bond of $\mathbf{1}$. 

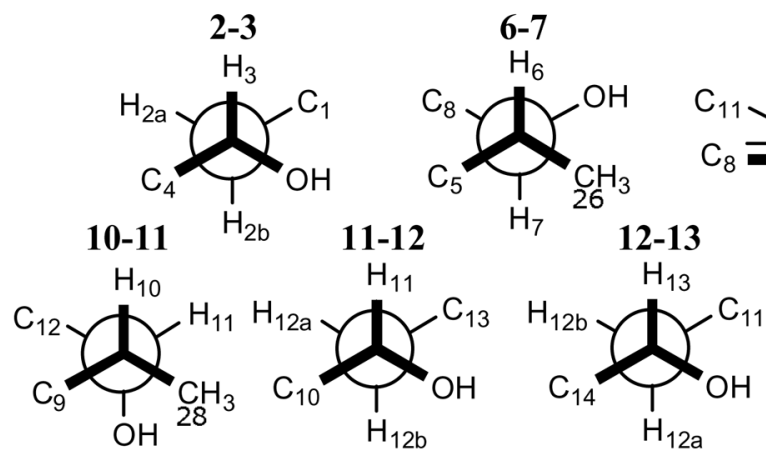

9-10
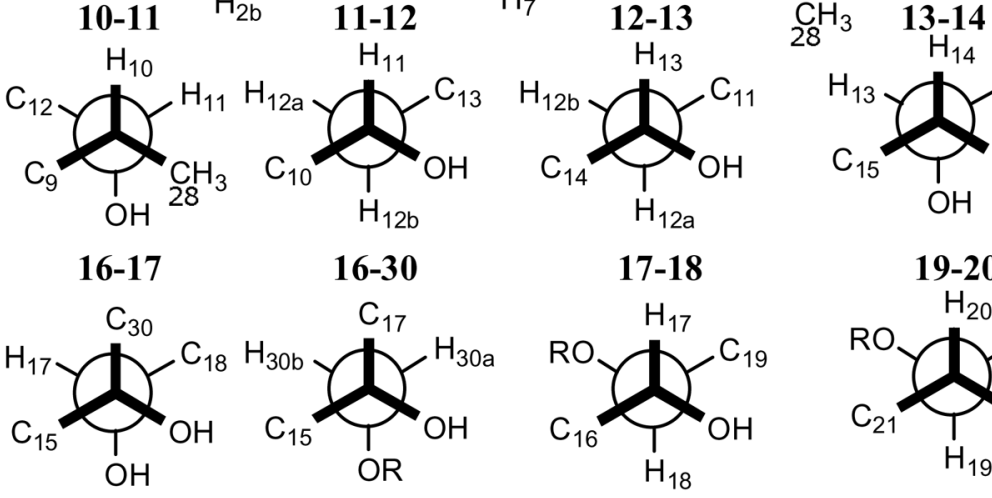

$\mathrm{CH}_{3} \quad \mathbf{1 3 - 1 4}$

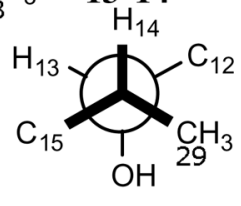

Figure 3 .

Diagram of the rotamers determined for C-C bonds of tedanolide C (1). 

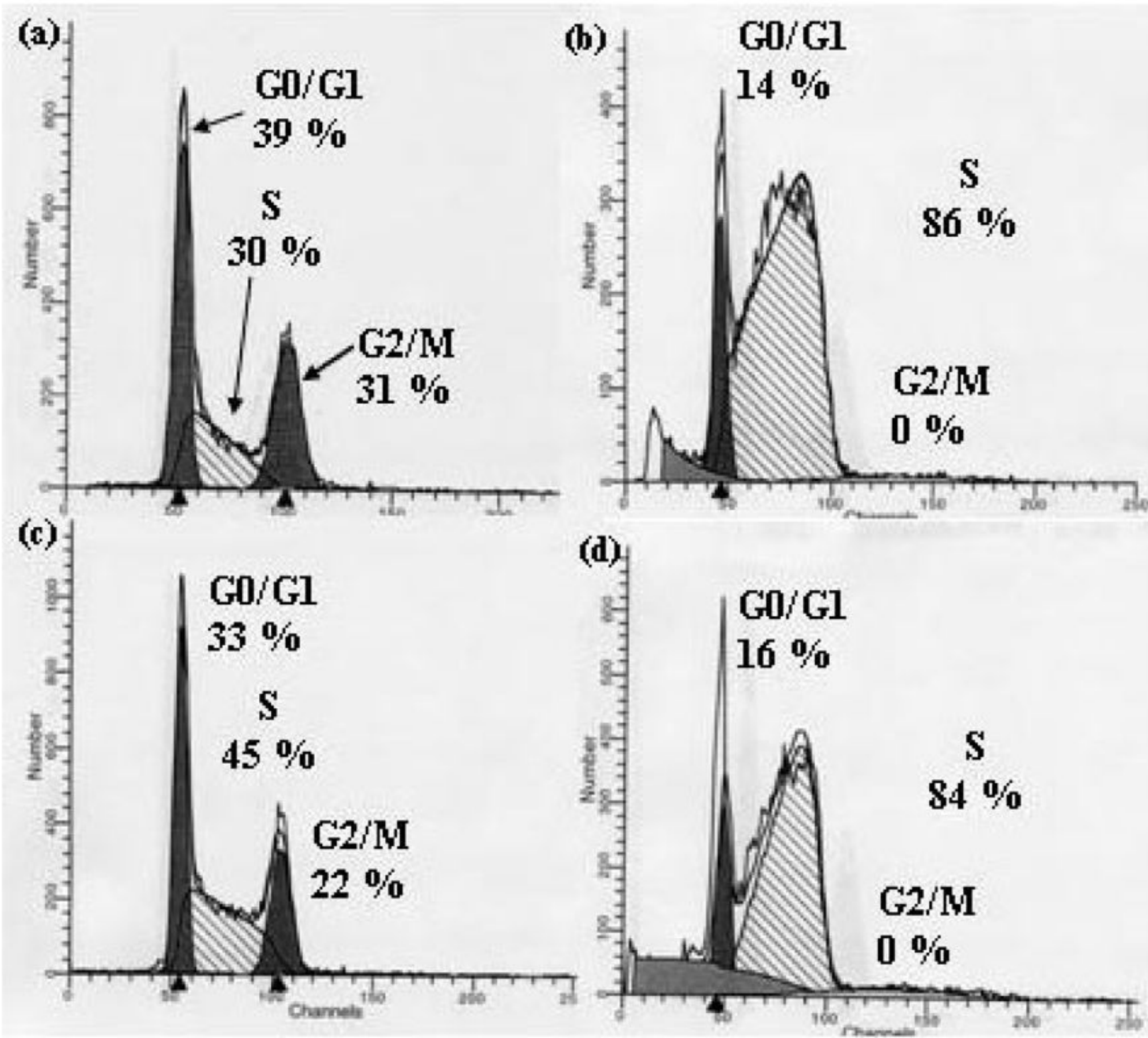

Figure 4.

The effect of tedanolide $\mathrm{C}(\mathbf{1})$ on cell cycle progression in HCT-116 cells as compared to vehicle. The treatments are as follows : (a) control, $24 \mathrm{~h}$; (b) $0.2 \mu \mathrm{g} / \mathrm{mL}$ (1), $24 \mathrm{~h} \mathrm{;} \mathrm{(c)} \mathrm{control,}$ $48 \mathrm{~h}$; d) $0.2 \mu \mathrm{g} / \mathrm{mL}(\mathbf{1}), 48 \mathrm{~h}$. 


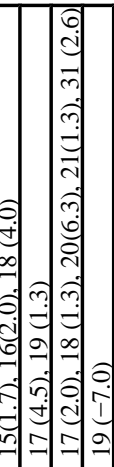

政

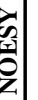

ปั

守岛

= 